\title{
Correspondence
}

CHI. \& WTO ReV. 2016:1; 123-134

http://dx.doi.org/10.14330/cwr.2016.2.1.06

pISSN 2383-8221 • elSSN 2384-4388

China and WTO Review

\section{HKND and the Canal de Nicaragua}

\author{
Yeonju Jo ${ }^{*} \&$ Luisa F. Reyes ${ }^{* *}$
}

\section{Overview: Recent FDI Inflow to Nicaragua}

Recently, the Foreign Direct Investment ("FDI") inflows into Nicaragua have begun to rise. In 2015, the FDI volume marks about six percent of GDP. In 2013, Nicaragua attracted USD 1.5 billion of FDI, a 17 percent increase from 2012 , reaching the highest level in seven years. ${ }^{1}$ Investments in mining, energy, service and tax-free zones posted the great attraction. In relation to GDP, their proportion was the highest in Central America. As free-trade zones have strongly supported the growth of FDI, the country is expected to attract more than USD 11 billion by $2016^{2}$

The Law to Promote Foreign Investment [Ley de Promoción de Inversiones Extranjeras], enacted in 2000, allows foreign investors to hold up to 100 percent of capital in all sectors. ${ }^{3}$ The Law guarantees the repatriation of capital and profits, as well as fast and efficient compensation in cases of expropriation for public interest reasons. ${ }^{4}$ It also allows investors to choose their arbitration tribunal in the event of conflict. $^{5}$

Nicaragua, however, has several weaknesses in attracting foreign investment, such as lack of data and information on local institutions and bureaucratic court system. According to the "2015 Doing Business" report issued by the World Bank, Nicaragua ranked in 119th out of 189 countries. ${ }^{6}$ Table 1 shows the Nicaragua's

* Latin American attaché of the Korea Importers Association. She may be contacted at: yjjo@ hotmail.com

** Monterrey Institute of Technology and Higher Education, Guadalajara, Mexico. She may be contacted at: : luisa_morales21@hotmail.com 
Ranking of 'Doing Business.'

Table 1: Nicaragua's Ranking of 'Doing Business'

\begin{tabular}{c|c|c}
\hline 119 & Nicaragua & $58.09 \uparrow$ \\
\hline 120 & Brazil & $58.01 \uparrow$ \\
\hline 121 & St. Kitts and Nevis & $58.00 \uparrow$ \\
\hline
\end{tabular}

Note: The rankings are benchmarked to June 2014 and based on the average of each economy's distance to frontier (DTF) scores for the 10 topics included in this year's aggregate ranking.

In order to improve her foreign investment environment, Nicaragua is especially expected to further develop local infrastructure systems such as a pipeline connecting the opposite coasts, railways, free trade zones, deep water ports, and a new international airport. Another noticeable project is the Grand Canal being financed by Chinese investors.

\section{Design}

The Nicaraguan Grand Canal (Canal de Nicaragua) Project began in June 2013 when the Nicaragua's National Assembly approved a bill to grant a 50-year concession to finance and manage the project to the private Hong Kong Nicaragua Canal Development Investment Company (hereinafter HKND Group) headed by Wang Jing. ${ }^{8}$ The concession can be extended for another 50 years once the waterway is operational. The Canal construction is estimated to cost up to USD 40-50 billion with completion scheduled in five years. ${ }^{9}$

The Canal will be located in southern Nicaragua. It would traverse the country from the Pacific shoreline near Brito, up the Rio Brito valley, over the continental divide, and down the Rio Las Lajas valley to Lago de Nicaragua approximately 4 kilometers south of the town of San Jorge. It would then cross Lago de Nicaragua approximately 4 kilometers south of the Isla de Ometepe, reaching the eastern Lago de Nicaragua shoreline about 8 kilometers south of the town of San Miguelito. It would then move up the Rio Tule stream valley and over the Caribbean highlands, with a maximum elevation along the canal alignment of 224 
meters. It would then traverse down the Rio Punta Gorda valley to the Caribbean shoreline about 1 kilometer north of the mouth of the Rio Punta Gorda (Figure 1 / Table 2). ${ }^{10}$

\section{Figure 1: The Nicaraguan Grand Canal Design ${ }^{11}$}

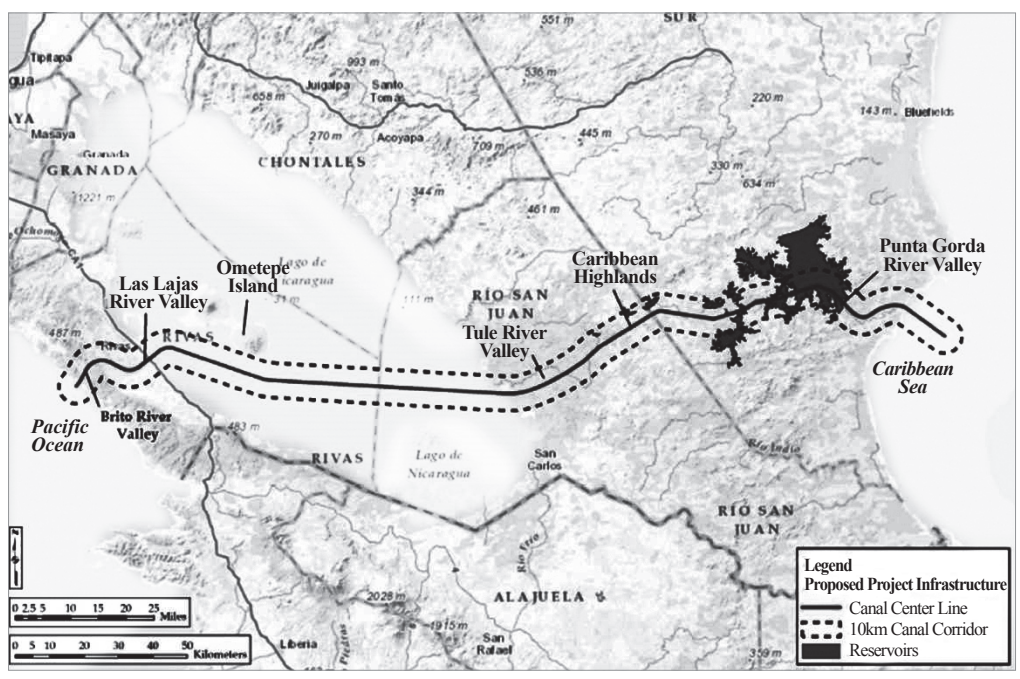

Table 2: Grand Canal Dimensions ${ }^{12}$

\begin{tabular}{l|c|c|c|c}
\hline \multicolumn{1}{c|}{ Canal Sections } & $\begin{array}{c}\text { Length } \\
(\mathbf{k m})\end{array}$ & $\begin{array}{c}\text { Bottom } \\
\text { Elevation } \\
\mathbf{( m )}\end{array}$ & $\begin{array}{c}\text { Design } \\
\text { Minimum } \\
\text { Depth(m) }\end{array}$ & $\begin{array}{c}\text { Typical } \\
\text { Canal Bottom } \\
\text { Width(m) }\end{array}$ \\
\hline Pacific Ocean & 1.7 & -30.2 & 29.0 & 280 \\
\hline Pacific coast to the Brito Lock & 12.5 & -30.2 & 29.0 & 280 \\
\hline Brito Lock to Lake Nicaragua & 13.4 & 3.25 & 26.9 & 230 \\
\hline Lago de Nicaragua & 106.8 & 1.75 & 28.4 & 280 \\
\hline Lake Nicaragua to Camilo Lock & 105.6 & 3.25 & 26.9 & 230 \\
\hline Camilo Lock to the Caribbean coast & 21.1 & -29.8 & 29.0 & 280 \\
\hline Caribbean sea & 14.4 & -29.8 & 29.0 & 280 \\
\hline Total length & 275.5 & NA & NA & NA \\
\hline
\end{tabular}

Note: $\mathrm{km}=$ kilometers $/ \mathrm{m}=$ meters $/ \mathrm{NA}=$ not applicable 
Once constructed, the Nicaraguan Grand Canal will be the biggest interoceanic waterway in the American continent. The largest container ships (target vessel) that the Canal can accommodate are currently 19,300 twenty-foot equivalent units (TEU) containers, so the 25,000 TEU ship dimensions are estimates. The Canal as constructed is itself likely to influence the actual dimensions of the largest ships, as has the Panama Canal. ${ }^{13}$

Table 3: Target Vessel Dimensions ${ }^{14}$

\begin{tabular}{c|c|c|c|c}
\hline Dimensions & $\begin{array}{c}\text { Dry Weight Tonnage (DWT) } \\
\text { Ship Vessels Container } \\
\text { Capacity (TEU) }\end{array}$ & $\begin{array}{c}\text { Overall } \\
\text { Length } \\
\text { (m) }\end{array}$ & $\begin{array}{c}\text { Type } \\
\text { Width } \\
\text { (m) }\end{array}$ & $\begin{array}{c}\text { Fully } \\
\text { loaded draft } \\
\text { in seawater } \\
\text { (m) }\end{array}$ \\
\hline Container Ships & 25,000 TEU & 500 & 72 & 18 \\
\hline $\begin{array}{c}\text { Very Large Crude Carriers } \\
\text { (VLCC) }\end{array}$ & 320,000 DWT & 330 & 60 & 20 \\
\hline $\begin{array}{c}\text { Ultra-large Bulk Carriers } \\
\text { (ULBC) }\end{array}$ & 400,000 DWT & 365 & 65 & 23.5 \\
\hline
\end{tabular}

TEU=twenty-foot equivalent units: $m=$ meters

Each ship can cross the Grand Canal within 30 hours. It is estimated that 5,100 ships will make use of this option as Asia becomes connected to western North America. ${ }^{15}$

The history of attempts to build a Nicaragua canal, connecting the Caribbean Sea and thus the Atlantic Ocean and the Pacific Ocean, goes back at least to the year of 1825 when the Federal Republic of Central America hired surveyors to study a route via Lake Nicaragua. As the long history illustrates, its regional and commercial demand in building the second largest canal stayed constant continued. With the globalization, shipping trade volume exceeds far above the transportation capacity of the Panama Canal, which has led to calls for a second canal construction to begin in the region. In 2006, the president of Nicaragua, Enrique Bolaños, announced Nicaragua's intent to proceed the project. ${ }^{16}$ Responding to this announcement, a Chinese billionaire, Wang Jing decided to invest in one of the world's largest engineering projects, "Canal de Nicaragua" that is three times the size of the Panama Canal. ${ }^{17}$ 


\section{Progress}

At the project's ribbon cutting ceremony, Vice President of Nicaragua Moses Omar Halleslevens said: "Today, we will start this majestic, great work, known as the Grand Canal is given." ${ }^{18}$ This grand public investment project has been carrying out by the HKND Group, a private infrastructure development firm that is based in Hong Kong and registered in the Cayman Islands. HKND was founded in 2012 for the purpose of developing the Canal. The Group is owned and controlled by a Chinese billionaire, Wang Jing. ${ }^{19}$

Cargo ships are expected to cross the Canal de Nicaragua in December 2019. It is, however, not yet perceived as economically helpful for many sectors of Nicaraguan society. The HKND Group acknowledged that the main construction would start from the end of $2016 .{ }^{20}$ The company said "the design of the canal is being fine-tuned," in accordance with recommendations from an environmental impact assessment. However, Wang Jing appears to be determined to push ahead with the canal project. ${ }^{21}$

Reviewing the Framework Agreement of the canal work, however, an environmental lawyer named Mónica López Baltodano explained that HKND Group needs at least 16 years: 6 years for financing and 10 years for construction, before the Grand Canal is open to the public, so that the work would not be ready in five years. ${ }^{22}$ Few shipping industry observers forecast a need for a second canal in the region especially to accommodate extra-large bulk cargo ships that are not commonly used yet. ${ }^{23}$

\section{Pros and Cons}

\section{A. The Positive}

The positive scenario proposes that the canal will improve the national economy. The canal would also provide a cheaper route that accommodates the increasingly large ships used to transport goods from the eastern US to the West Coast, and from Latin America to Asia. ${ }^{24}$ The HKND Group said the Nicaragua canal would employ 50,000 workers during the construction phase and create another 100,000 permanent jobs when completed. ${ }^{25}$ The Nicaragua canal construction project is 
also expected to bring an enormous economic effect on Latin America attracting China's huge investments.

One of the promises of the Grand Canal Interoceanic was that one million jobs would be created. Manuel Coronel Kautz, President of the Grand Canal Interoceanic, said in January 2014 that: "It is estimated about one million people needed to work in implementing the megaproject.." ${ }^{26} \mathrm{~A}$ year later, however, they lowered projections. HKND published on its website that: "More than fifty thousand workers will participate directly in the construction of this project. The operation stage will generate over two hundred thousand jobs." ${ }^{27}$ HKND said half of the 50,000 jobs would be for Nicaraguans, while the half would be for foreign technicians including Asians. ${ }^{28}$

\section{B. The Negative}

Mr. Daniel Ortega urged Chairman of the National Assembly to pass the law for the construction of a canal on June 14, 2013. This law, however, was not consulted by nation. LA PRENSA, a major newspaper of Nicaragua, reported that the agreement which was signed by HKND is against Nicaragua's national law and it does not contain any administrative, civil or criminal liability. ${ }^{29}$

The spokesman of Commission of Grand Canal, Telemaco Talavera said that adjusting the path of the Canal to protect the town of El Tule in San Juan River will cost approximately USD 700 million. He maintained:

To protect wetlands costs about seven hundred million dollars, only this route would be changed. If there was a purely commercial logic, why we will spend seven hundred million more, we're not talking about little money, but environmental and social logic are matters more important. ${ }^{30}$

Worse is that the Nicaraguan government has yet to release promised analyses of the canal's likely environmental impacts; it has even dodged neighboring Costa Rica's request to share disaster plans. Jorge A. Huete-Pérez, vice-president of the Academy of Sciences of Nicaragua, says that the government does not have enough information on a potentially big threat to the environment, but just wants to rush the thing through. He also said that the true benefits cannot be calculated yet. $^{31}$

If the canal is completed, 55 miles of its waterway would cut across the 
freshwater lake, transforming its bed and local rivers which could make this main source of the country's drinking water no longer potable. ${ }^{32}$

Environmentalists and scientists pointed out that the project may put risks upon extreme pollution-free wetlands and rainforests as well as Lake Nicaragua, Central America's largest freshwater reservoir. They also indicated that the canal would block the trans-traffic of the nature in the Mesoamerican Biological Corridor, where the nature and all species migrate and cross throughout the region. ${ }^{33}$ Yunsong Dong, an engineer of HKND, however, refuted that the Grand Canal would not cause any serious impact on water resources because "water collected in the Basin of Punta Gorda River was sufficient enough to operate the Canal...",34

People also oppose the project, because they are losing their land or Lake Nicaragua, Central America's largest freshwater lake. ${ }^{35}$ Wang Jing, the chief behind this project, however, assured in the viability of the project and keeps silent against all criticism just proposing facts and results. ${ }^{36}$

\section{Legal Ground}

The National Assembly of Nicaragua approved Law 800 (July 2012) providing a solid legal foundation for the construction of the Interoceanic Canal. Article 3 of Law 800 provides that: "The State of Nicaragua will receive 51 percent of the benefits of the Grand Canal Company of Nicaragua." ${ }^{37}$ By September 6, 2012, the Authority of the Grand Inter-Ocean Canal of Nicaragua signed a memorandum of understanding with HKND Group, establishing the project scope. ${ }^{38}$

The Deed of Cooperation was signed by both parties on October 31, 2012. The Authority agreed to give exclusive rights to the HKND Group to plan, design, construct, operate and manage the Nicaragua Grand Canal and other related projects such as ports, free trade zone, an international airport and other infrastructure development projects. ${ }^{39}$ Finally, on June 13, 2013, the Nicaraguan National Assembly gave its approval for the government to sign the Master Concession Agreement with the HKND Group. ${ }^{40}$

In June 2013, Law 840 was passed in the National Assembly to repeal the previous Law 800 . Here, the terms were changed. ${ }^{41}$ Article 10 provides: 
Nicaragua will receive annual cash payments up to ten million dollars over ten years...The right to participate in the each subproject under the terms of the MCA for economic profit, with equity represented initially by one percent of the subprojects held directly or indirectly by the investor. ${ }^{42}$

\section{A Challenge}

There are many unexpected challenges related to the construction project. The President of the Nicaraguan Development Institute (INDE), Sergio Arguello believes that vocational and technical training of Nicaragua is not ready, but there is still time for training. He stated:

I think Nicaragua lacks of experts on canal construction. We have no experience, we have never constructed on a large scale in Nicaragua. We have to rely on foreign companies, but also we can prepare by establishing training centers for peoples to be experts. ${ }^{43}$

Professionals and technicians from different areas should be committed to the construction and subsequent operation of the megaproject.

\section{Conclusion}

The Nicaraguan Grand Canal project may illustrate China's landmark foothold into Nicaragua in a region that has traditionally been under the American sphere of influence. The projected depth of the canal would be 28 meters, more than twice the Panama Canal. Foreign Policy observed that it is deep enough to allow Chinese submarines to secretly cross over the Atlantic Ocean from the Pacific. ${ }^{4}$

The Chinese government denies it is behind the project. ${ }^{45}$ No one, however, fully believes that the HKND Group alone can raise USD 50 billion. Wang Jing has not yet disclosed the investors willing to front the needed USD 50 billion. There is another story about this project. The Chinese government might back up the project for geopolitical reasons, particularly to challenge the US in the Caribbean area. As one of the few remaining States still recognizing Taiwan, 
Nicaragua would be a bridgeport for connecting China to Latin America.

Until now, there is no conclusive evidence that all of this is true. Wang once worked for a government telecom company, but is not known for especially close links to the Chinese leadership. Beijing seems wary of a project that could step on America's toes. ${ }^{46}$ State-owned companies have also steered the project because Nicaragua does not have formal diplomatic relations with China.

Another credible position is that Wang is interested not only in the canal, but also a network of ports, roads, and free trade zones. ${ }^{47}$ Nicaragua is listed as one of the 16 countries that are able to replace China as the major low-cost manufacturers, so Wang would have such blueprint. ${ }^{48}$

\section{REFERENCES}

1. R. Ray \& K. Gallagher, Global Economic Governance Initiative, China-Latin America Economic Bulletin 2015, Sept. 2015, available at http://www.bu.edu/pardeeschool/ files/2015/02/Economic-Bulletin-2015.pdf (last visited on February 10, 2016).

2. Id.

3. LPFI (Ley de Promoción de Inversiones Extranjeras [Law of Foreign Investment Promotion]) art. 5, available at http://legislacion.asamblea.gob.ni/Normaweb.nsf/(\$All)/A5C6D6F25A6B 2C7C06257213005F7EBC?OpenDocument (last visited on Feb. 18, 2016).

4. Id.

5. LPFI art 8.

6. World Bank, Doing Business 2015: Going beyond Efficiency 4 (Table 1.1), available at http://www.doingbusiness.org/ /media/GIAWB/Doing\%20Business/Documents/AnnualReports/English/DB15-Chapters/DB15-Report-Overview.pdf (last visited on Feb. 18, 2016).

7. UK Government Digital Service, Doing business in Nicaragua: Nicaragua trade and export guide, Aug. 11, 2015, available at https://www.gov.uk/government/publications/exporting-tonicaragua/doing-business-in-nicaragua-nicaragua-trade-and-export-guide (last visited on Feb. 18, 2016).

8. W. Jonathan, Nicaragua fast-tracks Chinese plan to build canal to rival Panama, GuARDiAn, June 12, 2013, available at http://www.theguardian.com/world/2013/jun/11/nicaraguachinese-plan-canal-panama (last visited on Jan. 18, 2016).

9. F. Michael, Chinese Billionaire Says Nicaragua Canal Has Investors, Bloomberg News, June 25, 2013, available at http://www.bloomberg.com/news/articles/2013-06-25/chinesebillionaire-says-nicaragua-canal-attracts-global-funding (last visited on Jan. 18, 2016).

10. HKND Group, Nicaraguan Canal Project Description, at 1, available at http://hknd-group. 
com/upload/pdf/20150105/Nicaragua_Canal_Project_Description_EN.pdf (last visited on Feb. 15, 2016).

11. Id. at 2 (Figure 2-1: Project Location).

12. Id. at 5 (Table 3.1-1).

13. Id. at 7 .

14. Id. (Table 3.1-2).

15. L. Alvarez, HKND presenta ruta del Gran Canal de Nicaragua [HKND present a route of the Grand Canal of Nicaragua], LA Prensa, July 7, 2014, available at http://www.laprensa. com.ni/2014/07/07/nacionales/202195-hknd-presenta-ruta-del-gran-canal-de-nicaragua (last visited on Feb. 12, 2016).

16. T. Hector \& K. Chris, Rival to Panama Canal Planned, L.A. Times, Sept. 30, 2006, available at http://articles.latimes.com/2006/sep/30/business/fi-canal30 (last visited on Jan. 18, 2016).

17. Lily Kuo, Why is a Chinese tycoon building a $\$ 50$ billion canal in Nicaragua that no one wants?, QUARTZ, June 17, 2015, available at http://qz.com/430090/why-is-a-chinese-tycoonbuilding-a-50-billion-canal-in-nicaragua-that-no-one-wants (last visited on Jan.. 18, 2016).

18. See Gobierno inaugura obras de inicio del gran Canal [Government inaugurates initial of the Grand Canal's work], LA PrENSA, Dec. 22, 2014, available at http://www.laprensa.com. ni/2014/12/22/nacionales/1668465-gobierno-inaugura-obras-del-gran-canal-interoceanicode-nicaragua (last visited on Feb. 18, 2016).

19. HKND Group, Business Insight in Latin America, available at http://www.bnamericas.com/ company-profile/en/hknd-group-hknd (last visited on Feb. 12, 2016).

20. Rezaye Alvarez M., El Gran Canal, una obra sin iniciar [The Grand Canal, a work without beginning], LA PRENSA, Dec. 20, 2015, available at http://www.laprensa.com.ni/2015/12/20/ nacionales/1957359-gran-canal-una-obra-sin-iniciar (last visited on Feb. 12, 2016).

21. Supra note 17

22. Ilich Buitrago Aguilar, Si acaso hay Canal será hasta 2029 [If there is Canal, it will be until 2029], La Prensa, Feb. 20, 2015, available at http://www.laprensa.com.ni/2015/02/20/ nacionales/1786070-si-acaso-hay-canal-sera-hasta-2029-si-acaso-hay-canal-sera-hasta-2029 (last visited on Feb. 12, 2016).

23. Supra note 8

24. E. Zach, In Paradisiacal Nicaragua, Contemplating a Canal, N.Y. Times, Apr. 24, 2015, available at $\mathrm{http} / /$ www.nytimes.com/2015/04/26/travel/26nicaragua-cover.html?smid=fbnytimes\&smtyp $=$ cur\&bicmp $=$ AD\&bicmlukp $=$ WT.mc_id\&bicmst $=1409232722000 \&$ bicm et $=1419773522000 \& \_r=0$ (last visited on Jan. 18, 2016).

25. P. Leach, Prospect of Nicaragua canal stumps industry observers, JOC, July 28, 2014, available at $\mathrm{http}: / / \mathrm{www}$.joc.com/maritime-news/international-freight-shipping/prospectnicaragua-canal-stumps-industry-observers_20140728.html (last visited on Jan. 18, 2016).

26. V. Vasquez, Siete mentiras del Canal [Seven lies of Canal], La Prensa, Jan. 18, 2015, 
available at http://www.laprensa.com.ni/2015/01/18/nacionales/1766881-15374 (last visited on Feb. 12, 2016).

27. Id.

28. $I d$.

29. E. Cardenal, La monstruosidad del Canal [The monstrosity of the Canal], LA Prensa, Nov. 1, 2014, available at http://www.laprensa.com.ni/2014/11/01/columna-del-dia/216594-dlamonstruosidad-del-canal (last visited on Feb. 16, 2016).

30. C. Solorzano, Canal, US\$700 millones más caro [Canal, \$ 700 million more expensive], La Prensa, May 24, 2015, available at http://www.laprensa.com.ni/2015/05/24/ nacionales/1837640-canal-us700-millones-mas-caro-canal-us-700-millones-mas-caro (last visited on Feb. 12, 2016).

31. M. Shaer, A New Canal through Central America Could Have Devastating Consequences, Smithsonian, Dec. 2014, available at http://www.smithsonianmag.com/science-nature/newcanal-through-central-america-could-have-devastating-consequences-180953394/?no-ist (last visited on Jan. 16, 2016).

32. Supra note 24

33. C. Kraul, Nicaragua canal raises questions that remain unanswered, says study, L.A. Times, Oct. 1, 2015, available at http://www.latimes.com/world/mexico-americas/la-fg-nicaraguacanal-environment-20151001-story.html (last visited on Feb. 12, 2016).

34. Supra note 15

35. S. Pendergast, Wang Jing of China plans for canal through Nicaragua, Spendergast, June 21, 2015, available at http://spendergast.blogspot.kr/2015/06/wang-jing-of-china-plans-forcanal.html (last visited on Feb. 12, 2016).

36. See Wang Jing sigue sin explicar cómo conseguirá dinero para canal [Wang Jing does not yet explain how to get the money for the canal], LA Prensa, Mar. 19, 2015, available at http:/www.laprensa.com.ni/2015/03/19/nacionales/1801640-wang-jing-sigue-sin-explicarcomo-conseguira-dinero-para-canal (last visited on Feb. 15, 2016).

37. Law 800 art. 3 (Naturaleza/Nature). It provides :

La Autoridad de El Gran Canal Interoceánico de Nicaragua no estará sujeta al pago de impuestos...

...El Estado de Nicaragua se beneficiará del cincuenta y uno por ciento (51\%) de los beneficios netos

de la Empresa Gran Nacional de El Gran Canal de Nicaragua recibidos de la Autoridad de El Gran

Canal Interoceánico de Nicaragua.

available at http://legislacion.asamblea.gob.ni/SILEG/Iniciativas.nsf/0/1c79b32dfa494db9 06257a14007fb07f/\$FILE/Ley\%20No.\%20800\%20E1\%20Gran\%20Canal.pdf (last visited on Feb. 15, 2016).

38. HKND Group, Project Background, 2015, available at http://hknd-group.com/portal. php?mod=list\&catid=42 (last visited on Feb. 16, 2016).

39. Id.

40. Id. 
41. Supra note 26 (Las Ganancias de Nicaragua/The profits of Nicaragua).

42. Law 840 art. 10 (Economía/Economy). It provides:

Como contraprestación por el otorgamiento de las concesiones y otros derechos previstos en virtud del MCA y ratificados por la presente Ley, El Inversionista estará obligado a procurar que se entregue a la Autoridad de El Gran Canal Interoceánico de Nicaragua lo siguiente: a) Pagos anuales en efectivo por un monto de hasta Diez Millones de Dólares de los Estado Unidos de América (US\$10,000,000) por año durante diez (10) años, según se detalla y sujeto a los términos establecidos en El MCA, incluyendo sus tiempos y las reducciones que debieren realizarse a dichos pagos;

available at http://legislacion.asamblea.gob.ni/SILEG/Gacetas.nsf/5eea6480fc3d3d900625 76e300504635/f1ecd8f640b8e6ce06257b8f005bae22/\$FILE/Ley\%20No.\%20840.pdf (last visited on Feb. 15, 2016).

43. A. Sepulveda, Los retos profesionales que plantea el Canal a Nicaragua [The professional challenges posed by Nicaragua Canal], El Nuevo Diario, Feb. 9, 2015, available at http:// www.elnuevodiario.com.ni/economia/341309-retos-profesionales-que-plantea-canalnicaragua (last visited on Feb. 12, 2016).

44. D. Runde, China's Canal in Nicaragua?, Foreign PoL'y, May 26, 2015, available at http:// foreignpolicy.com/2015/05/26/should-the-us-worry-about-chinas-canal-in-nicaragua (last visited on Feb. 12, 2016).

45. M. O’Grady, China Wants to Dig the Nicaragua Canal, Wall St. J., Aug. 9, 2015, available at http://www.wsj.com/articles/china-wants-to-dig-the-nicaragua-canal-1439159390 (last visited on Feb. 12, 2016).

46. Supra note 8.

47. Id.

48. Supra note 1. 